DOI: $10.4274 /$ tpa.46.82

\title{
Doğu Anadolu bölgesinde gebelerde ve doğan bebeklerinde demir durumu ve süt çocuklarında demir desteği gerekliliği
}

\author{
Iron status of pregnant women and their newborns, and the necessity of iron \\ supplementation in infants in Eastern Turkey
}

\author{
Hatice Gamze Poyrazoğlu, A. Denizmen Aygün* Bilal Üstündağ ${ }^{\star *}$, Saadet Akarsu*, Serap Yıldırmaz* \\ Erciyes Üniversitesi Tıp Fakültesi, Çocuk Sağlı̆ı ve Hastalıkları Anabilim Dalı, Kayseri, Türkive \\ ${ }^{*}$ Fırat Üniversitesi Tıp Fakültesi, Çocuk Sağığı ve Hastalıkları Anabilim Dalı, Elazı̆g, Türkiye \\ **Frrat Üniversitesi Tıp Fakültesi, Biyokimya Anabilim Dalı, Elazığ, Türkeye
}

Özet

Amaç: Yaşamın ilk iki yılı içerisindeki besinsel anemilerin en önemli nedeni demir eksikliği anemisidir. Bu çalışmada Doğu Anadolu Bölgesi'nde gebe kadınlarda ve doğan bebeklerinde demir durumunun tanımlanması ve yaşamın ilk yılı içerisinde ortaya çıkan demir eksikliği anemisine etkilerinin araştıııması amaçlandı.

Gereç ve Yöntem: Çalışma demir durumu ve demir desteğine göre dört grupta sınıflandııılan 92 gebe kadında gerçekleştirildi. Yerel etik kuruldan onay alındı (Fırat Üniversitesi Tıp Fakültesi Etik Kurulu 25.03.2004 tarih 4. Toplantı 2. Karar). Gebe kadınlar 14. haftadan itibaren izlendi ve venöz kan örnekleri başvuruda, bebeklerinden ise doğumda, üçüncü, altıncı ve on ikinci ayda elde edildi. Kan örneklerinde tam kan sayımı yanında serum demiri, ferritin ve demir bağlama kapasitesi değerlendirildi. İstatistiksel yöntem olarak tek yönlü Varyans analizi (ANOVA) ve Pearson ve Spearman rank testi uygulandı.

Bulgular: Doğumda dört grup arasında serum demir ve ferritin düzeyleri açısından anlamlı fark yoktu $(p<0,05)$. Üçüncü ayda, serum demir değerleri fizyolojiye uygun olarak azaldı ve altıncı ayda, birinci grupta $\% 40$, ikinci grupta $\% 57,1$, üçüncü grupta $\% 50$ ve dördüncü grupta $\% 69,2$ oranında demir eksikliği anemisi gelişti.

Çıkarımlar: Bebeklerin demir durumu doğumdaki demir depolarıyla belirlenemez, yaşamın birinci yılında beslenme de etkilidir. Çalışmada doğumda demir depolarının yeterli olmasına karşın altıncı ayda bebeklerin yarısında demir eksikliği anemisi gelişti. Doğu Anadolu Bölgesinde çocuklarda üçüncü aydan itibaren demir desteği gereklidir. (Türk Ped Arş 2011; 46: 246-51)

Anahtar sözcükler: Demir desteği, demir durumu, demir eksikliği anemisi, gebe kadın, süt çocuğu

\section{Summary}

Aim: Iron deficiency anemia is the most frequent cause of nutritional anemia in the first two years of life. The aim of this study was to evaluate iron status of pregnant women and their infants in Eastern Turkey and to determine their effects on iron deficiency anemia in the first year of life.

Material and Method: This study was realized on 92 pregnant women classified in four groups according to their iron status and iron prophylaxis. This study was approved by The Local Ethic Committee (Fırat Üniversitesi Tıp Fakültesi Etik Kurulu 25.03.2004, 4. Session). Pregnant women were followed from the $14^{\text {th }}$ week of gestation and blood samples of her were got at onset and of women were olatained infants at birth and on the third month, sixth month and twelfth month of life. Total blood count, serum ferritin and iron levels and total iron-binding capacity were evaluated. One way analysis of variance (ANOVA) and Pearson's and Spearman's rank test were used for statistical methods.

Results: At birth, serum iron and ferritin levels were not significantly different between the four groups $(p<0.05)$. At the third month of life; serum iron levels were diminished according to the physiologic changes and at the sixth month of life; iron deficiency anemia developed in $40 \%$ of the first group, in $57.1 \%$ of the second group, in $50 \%$ of the third group and in $69.2 \%$ of the fourth group.

Conclusions: Iron status of infants is not defined only by iron stores at birth, the nutrition during the first year of life is also effective. In this study, iron deficiency anemia developed in approximately $50 \%$ of infants at the sixth month of life; despite the iron storage was sufficient at birth. Supplementation of iron in infants living in Eastern Turkey is necessary from the third month of life. (Turk Arch Ped 2011; 46: 246-51)

Key words: Infant, iron deficiency anemia, iron status, iron supplementation, pregnant woman

Yazışma Adresi/Address for Correspondence: Dr. A. Denizmen Aygün, Fırat Üniversitesi Tıp Fakültesi Çocuk Sağıı̆ı ve Hastalıkları Anabilim Dalı, Elazığ, Türkiye E-posta: denizmen@gmail.com Geliş Tarihi/Received: 16.05.2010 Kabul Tarihi/Accepted: 03.02.2011

Türk Pediatri Arşivi Dergisi, Galenos Yayınevi tarafindan basılmıştır. / Turkish Archives of Pediatrics, published by Galenos Publishing 


\section{Giriș}

Gebe kadınlarda uygulanan demir tedavilerinin doğum öncesi ve sonrasında anne ve bebek üzerindeki etkileri konusunda bilgilerimiz yeterli değildir (1).

Yaşa ve cinse göre beklenen hemoglobin $(\mathrm{Hb})$ değerinin iki standart sapma altında olması anemi olarak kabul edilir (2). Anne adayında anemi ise gebelik süresinde hemoglobin değerinin $11 \mathrm{~g} / \mathrm{dL}$ altında olması olarak yorumlanır. Bu durumun oluşmasında diyetle alınan demir miktarı azlığı, sosyal durumun kötülügü ve gebelik öncesi annede anemi varlığı etkilidir $(3,4)$. Gebelik süresince anneden bebeğe demir geçişi gerçekleşir ve en yüksek geçiş oranına 30 . gebelik haftasında ulaşılır. Gelişmekte olan ülkelerde gebelik öncesi \%43 olan anemi sıklık oranı, gebelikle birlikte \%56 değerlerine yükselir (5).

Süt çocukluğu döneminin ilk üç ayında demir eksikliği anemisi tanısında plazma ferritin düzeylerinin $12 \mu \mathrm{g} / \mathrm{L}$ altında olma$\mathrm{SI}$, ilk altı ayında ise ferritin düzeyi yanında çinko protoporfirin düzeyinin $35 \mu \mathrm{g} / \mathrm{L}$ altında olması, hemoglobin değerinin $11 \mathrm{~g} / \mathrm{dL}$ altında olmasına göre daha anlamlı kabul edilir $(4,6,7)$.

Doğum sonrası ilk dört ayda demir depoları genellikle yeterli olduğundan demir desteği gerekli değildir. Daha sonraki dönemde hızlı büyüme devam ederken depolar azalma eğilimindedir. Bu dönemde diyetle emilmesi gereken 0,8 $\mathrm{mg} / \mathrm{gün}$ düzeyindeki demirin $0,6 \mathrm{mg} / \mathrm{gün}$ olan kısmı büyüme, geri kalan 0,2 mg/gün kısmı ise kayıpların karşılanması için kullanılır $(8,9)$.

Son yıllarda demir eksikliği anemisi olan çocuklarda düşük gelişimsel test değerlerinin ortaya konulması üzerinde durulması gereken bir sorundur $(8,10)$. Demir eksikliğinin dopaminerjik sinir iletisinde bozukluk oluşmasına neden olduğu ve buna bağlı olarak çocuklarda zihinsel gelişim ve işlev bozukluğu görülebileceği de bilinmektedir (11).

Annede transferine bağlanmış olarak bulunan demir plasentada transferin almaçlarına (reseptörlerine) aktarılır ve buradan bebeğe demir olarak geçiş gösterir. Bu taşınma yöntemi; ağır demir eksikliği bulunan anneler dışındaki gebelerden doğan bebeklerde demir eksikliği anemisinin ortaya çıkışını engeller $(12,13)$. Ancak, yenidoğan bebeğin demir durumu annenin demir durumu ile yakından ilişkilidir (14). Doğum sonrası oksijenlenmenin artması ve eritropoietin düzeyinin azalması ile eritrosit yapımı baskılanır. Bebeğin hızlı gelişiminin eşlik etmesi $\mathrm{Hb}$ yoğunluklarında belirgin azalmaya ve yaşamın ikinci, üçüncü aylarında en düşük düzeye inilmesine neden olur (14). Gebelerde demir tedavisinin tüm gebelere uygulanması tartışmalıdır ve gelişmiş ülkelerde bu uygulama yapılmamaktadır.

Bu çalışmada; Doğu Anadolu Bölgesi illerinden Elazığ'da deniz seviyesinden ortalama 1075 m yükseklikte yaşayan gebe kadınlarda demir eksikliği anemisi varlığının araştıııma$\mathrm{SI}$, anemisi olanlarda demir desteği uygulamalarının ortaya konulması, bu annelerden doğan bebeklerde demir eksikliği anemisi sıklığı ve ortaya çıkış zamanının gözlemlenmesi ve elde edilen sonuçlara göre bölgemizde doğan bebeklere demir desteği gerekliliğinin gösterilmesi amaçlandı.

\section{Gereç ve Yöntem}

Çalışmaya ilk olarak Ekim 2004 - Ekim 2005 tarihleri arasında Kadın Hastalıkları ve Doğum Anabilim Dalı polikliniğine gelen 14. gebelik haftası ve üzerindeki gebelerin değerlendirilmesi ile başlanıldı. Çalışmaya katılan tüm gebelerin doğumlarının gerçekleşmesi ve bebeklerinin bir yıl süresince izlenmesi ile devam edildi ve Aralık 2006 tarihinde çalışma sonlandııılı. Fırat Üniversitesi Tıp Fakültesi Etik Kurul onayı alındı (Fırat Üniversitesi Tıp Fakültesi Etik Kurulu 25.03.2004 tarih 4. Toplantı 2. Karar). Ayrıca çalışmaya katılan her anne bilgilendirildi. Kendisi için ve bütün anne ve babalardan bebekleri için yazılı onay alındı.

Gebelik süresince düzenli izlenen 76 gebeden sadece 22 gebenin doğumu hastanemizde gerçekleşti. Bu nedenle doğumu hastanemizde gerçekleşmeyen gebeler çalışma dışı bırakıldı. Bu sayı çalışma planında yetersiz kaldığından izlemleri hastanemiz dışında gerçekleşmiş, ancak kayıtları yeterli bulunan ve hastanemizde doğum yapan 174 gebeden doğum sonrası çocuklarını kontrole getiren 70 gebe de çalışma kapsamına alındı. Yaklaşık 26 gebelik haftası ve 52 hafta bebek izlemi olarak 250 gebe ve bebeği üzerinde planlanan çalışma sürenin uzunluğu nedeniyle hastaların izlemden çıkması sonucu 92 gebe ve çocuğu ile sonlandırıldı.

Çalışma grubuna alınan tüm gebelerin muayene sonuçları kayıt altına alındı. Ayrıca, her gebeden başvuru anında venöz kan örneği elde edildi; tam kan sayımı yanında serum demir ve ferritin düzeyleri, serum demir bağlama kapasitesi değerlendirildi. Hemoglobin düzeyleri $11 \mathrm{~g} / \mathrm{dL}$ altında olan tüm gebelere $60 \mathrm{mg} /$ gün olacak şekilde ferröz demir içeren destek başlandı.

Çalışma grubu gebelerin demir durumu ve gebelik süresince demir desteği verilmesine göre; gebelik süresince $\mathrm{Hb}$ değerleri anemik düzeyde olmayan (>11 g/dL) demir desteği alanlar birinci grup, demir desteği almayanlar ikinci grup, $\mathrm{Hb}$ değerleri anemik düzeyde olan $(<11 \mathrm{~g} / \mathrm{dL})$ demir desteği alanlar üçüncü grup ve demir desteği almayanlar (gebelik süresince yeterince izlenmemiş ve sadece doğum anında sağlık kuruluşuna başvuranlar) dördüncü grup olarak dört ayrı grupta değerlendirildi.

Çalışmaya kabul edilen gebelerden doğan bebeklerinden doğum anında, üçüncü, altıncı ve on ikinci aylarda venöz kan örneği alınarak tam kan sayımı, serum demir ve ferritin düzeyleri ve total demir bağlama kapasitesi değerlendirildi. Üçüncü ay sonrası anemi saptanan bebeklere $5 \mathrm{mg} / \mathrm{kg} / \mathrm{gün}$ şeklinde demir desteği sağlandı. Üç ay sonraki değerlendirmede anemi bulguları düzelenlerde demir desteği sonlandırıldı. Anne ve bebeklerden elde edilen kan tüm venöz kan örnekleri uygun koşullarda hazırlandıktan ve saklandıktan sonra uygun yöntemlerle Biyokimya Laboratuvar'ında çalışıldı.

Elde edilen veriler SPSS 11.0 paket programı kullanılarak istatistiksel olarak yorumlandı. Tüm değerler ortalama \pm standart sapma olarak gösterildi. Gruplar arası ve grupların kendi içerisinde karşılaştırmalarda tek yönlü varyans analizi (ANOVA) testi ve post hoc testlerden Tukey B ve Scheffe yöntemleri kullanıldı. Ayrıca bağıntıların gösterilmesi amacıyla Pearson Spearman sıra testi uygulandı. Tüm sonuçlarda $p<0,05$ değerler istatistiksel olarak anlamlı kabul edildi. 


\section{Bulgular}

Gebeler ve doğurdukları bebeklerine ait demografik bilgiler Tablo 1'de özetlendi. Gebeler ve doğurdukları bebeklerin özellikleri açısından gruplar arasında anlamlı fark gözlenmedi.

Gebelerin 14. gebelik haftası sonrası ve doğum öncesi elde edilen değerleri Tablo 2'de yer aldı. Anemik olan ve olmayan gebelerden demir desteği alanlar ve almayanlar arasında serum demir ve ferritin, demir bağlama kapasitesi düzeyleri,
$\mathrm{Hb}$ ve hematokrit düzeyleri açısından anlamlı fark bulunamadı. Ancak, anemik olmayan gebelerde de $\mathrm{Hb}$ değerleri doğumda $12,7 \pm 0,8 \mathrm{~g} / \mathrm{dL}$ (destek alanlar) ve 12,6 $\pm 0,8 \mathrm{~g} / \mathrm{dL}$ (destek almayanlar) olarak beklenen değerlere göre düşük saptandı.

Çalışmaya katılan gebelerden doğan bebeklerin ölçülen hematolojik ve demir durumu göstergeleri Tablo 3 ve 4'te özetlendi. Doğum anında anneleri anemik olmayan ve demir desteği alan bebeklerin serum ferritin düzeyleri anneleri anemik olan ve demir desteği almayan bebeklere göre istatistiksel ola-

Tablo 1. Anne ve bebeklerin demografik özellikleri

\begin{tabular}{|c|c|c|c|c|c|}
\hline & Grup $1(n=30)$ & Grup $2(n=27)$ & Grup $3(n=19)$ & Grup $4(n=16)$ & $p$ \\
\hline \multicolumn{6}{|l|}{ Anneler } \\
\hline Yaş (yıl) & $29,3 \pm 5,2$ & $28,4 \pm 6,1$ & $28,3 \pm 4,6$ & $28,5 \pm 6,5$ & $A D$ \\
\hline Gebelik sayısı & 2,50 & 3,04 & 3,00 & 2,31 & $A D$ \\
\hline Ölü doğum sayısı & 0,10 & 0,20 & 0,26 & 0,00 & \\
\hline Düşük sayısı & 0,30 & 0,19 & 0,37 & 0,13 & \\
\hline \multicolumn{6}{|l|}{ Bebekler } \\
\hline Cinsiyet (K/E) & $11 / 19$ & $16 / 11$ & $9 / 10$ & $10 / 6$ & \\
\hline Vücut ağırlığı (g) & $3041 \pm 420$ & $3186 \pm 626$ & $3233 \pm 522$ & $3134 \pm 471$ & $A D$ \\
\hline Boy $(\mathrm{cm})$ & $50,0 \pm 1,4$ & $49,6 \pm 1,3$ & $50,0 \pm 2,1$ & $49,9 \pm 2,0$ & $A D$ \\
\hline
\end{tabular}

AD: Anlamlı değil

Tablo 2. Gebelerin gebeliğin 14. haftası ve doğum sırasında demir durumu göstergeleri

\begin{tabular}{|c|c|c|c|c|c|}
\hline & Grup 1 & Grup 2 & Grup 3 & Grup 4 & $p$ \\
\hline 14.hafta & $12,4 \pm 1,0$ & $12,9 \pm 1,1$ & $10,5 \pm 0,2$ & $10,5 \pm 0,2$ & $<0,001$ \\
\hline Doğum & $12,7 \pm 0,8$ & $12,6 \pm 0,8$ & $10,3 \pm 0,6$ & $9,9 \pm 0,9$ & $<0,001$ \\
\hline
\end{tabular}

Hematokrit (\%)

\begin{tabular}{|l|l|l|l|l|l|}
\hline 14.hafta & $35,7 \pm 2,2$ & $37,6 \pm 2,6$ & $31,2 \pm 0,8$ & $31,4 \pm 0,6$ & $<0,001$ \\
\hline Doğum & $38,7 \pm 2,2$ & $37,9 \pm 3,8$ & $32,3 \pm 2,9$ & $31,2 \pm 2,9$ & $<0,001$ \\
\hline
\end{tabular}

Demir (mg/dL)

\begin{tabular}{|l|c|c|c|c|c|}
\hline 14.hafta & $65,3 \pm 19,0$ & $62,0 \pm 6,3$ & $28,2 \pm 4,3$ & $25,0 \pm 4,2$ & $<0,05$ \\
\hline Doğum & $57,4 \pm 26,8$ & $45,8 \pm 34,4$ & $45,1 \pm 28,8$ & $26,2 \pm 7,2$ & $<0,05^{\star}$ \\
\hline
\end{tabular}

Total demir bağlama kapasitesi $(\mu \mathrm{g} / \mathrm{dL})$

\begin{tabular}{|l|l|l|l|l|l|}
\hline 14.hafta & $393 \pm 25$ & $353 \pm 40$ & $410 \pm 36$ & $406 \pm 52$ & AD \\
\hline Doğum & $332 \pm 60$ & $363 \pm 77$ & $369 \pm 52$ & $362 \pm 57$ & $A D$ \\
\hline
\end{tabular}

Ferritin $(\mathrm{ng} / \mathrm{mL})$

\begin{tabular}{|c|c|c|c|c|c|}
\hline 14.hafta & $32,5 \pm 25,1$ & $34,2 \pm 15,1$ & $11,0 \pm 2,4$ & $13,0 \pm 2,8$ & $<0,05$ \\
\hline Doğum & $41,7 \pm 20,1$ & $42,0 \pm 27,8$ & $12,4 \pm 8,2$ & $12,6 \pm 3,5$ & $<0,05$ \\
\hline \multicolumn{5}{|l|}{} & \\
\hline Transferin satürasyonu (\%) & $16,7 \pm 5,2$ & $17,6 \pm 2,1$ & $6,7 \pm 1,1$ & $6,2 \pm 1,8$ & $<0,05$ \\
\hline 14.hafta & $18,2 \pm 13,4$ & $20,2 \pm 14,5$ & $12,4 \pm 8,2$ & $7,3 \pm 2,1$ & $<0,05$ \\
\hline Doğum
\end{tabular}


Tablo 3. Bebeklerin süt çocukluğu döneminde hematolojik göstergeleri

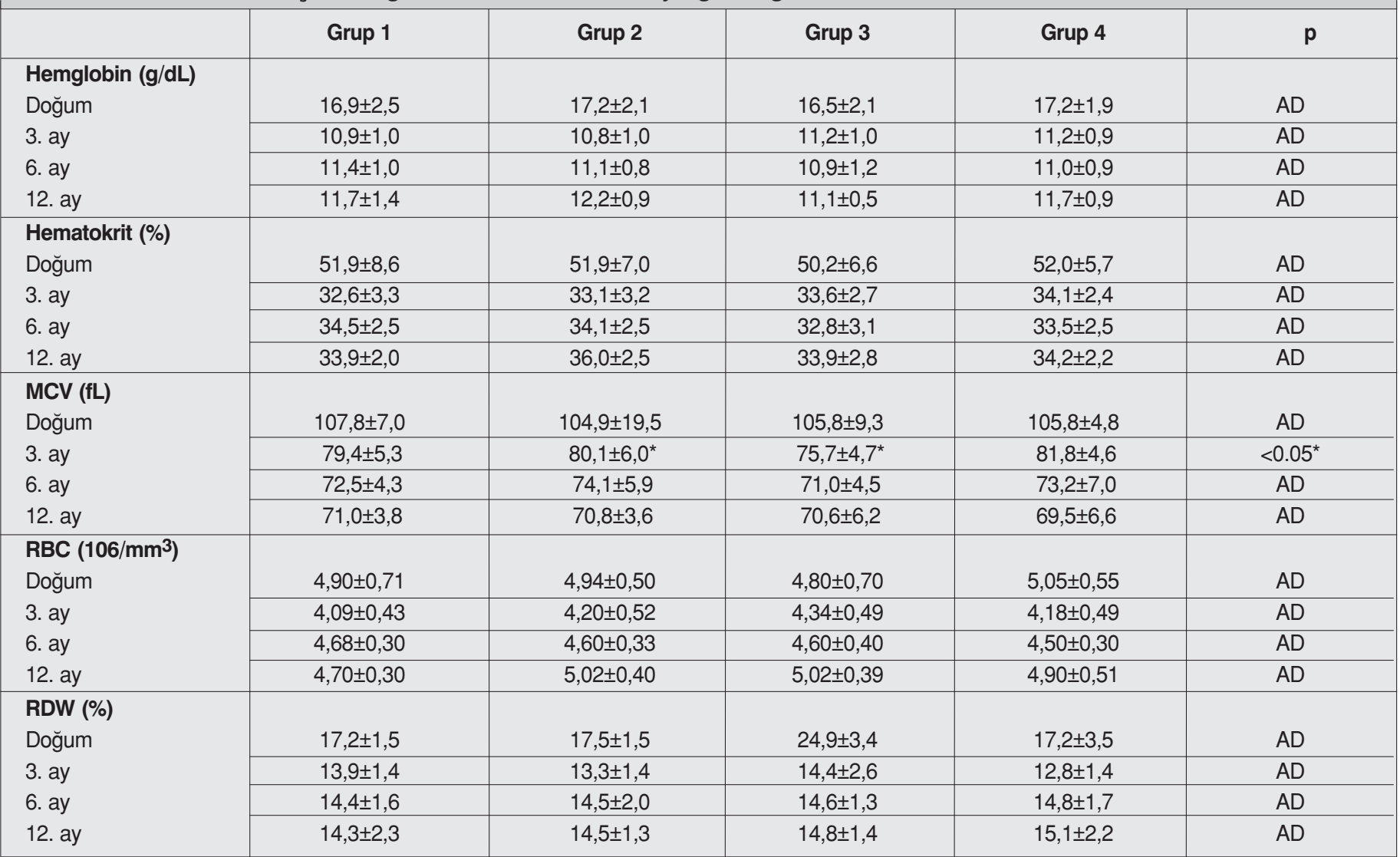

AD: Anlamlı değil, *Grup 1 ve 3 ile Grup 2 ve 4 arasında anlamlı

Tablo 4. Bebeklerin süt çocukluğu döneminde demir durumu göstergeleri

\begin{tabular}{|c|c|c|c|c|c|}
\hline & Grup 1 & Grup 2 & Grup 3 & Grup 4 & p \\
\hline Doğum & $68,1 \pm 49,6$ & $61,2 \pm 57,7$ & $71,6 \pm 52,8$ & $83,0 \pm 45,9$ & $A D$ \\
\hline 6. ay & $35,3 \pm 15,3$ & $32,9 \pm 13,1$ & $27,5 \pm 12,3$ & $35,6 \pm 15,8$ & $A D$ \\
\hline 12. ay & $43,9 \pm 32,0$ & $40,7 \pm 22,5$ & $28,8 \pm 14,4$ & $37,3 \pm 14,4$ & $A D$ \\
\hline \multicolumn{6}{|c|}{ Total demir bağlama kapasitesi $(\mu \mathrm{g} / \mathrm{dL})$} \\
\hline 3. ay & $304,0 \pm 74,4$ & $288,3 \pm 59,4$ & $300,2 \pm 37,2$ & $334,0 \pm 76,4$ & $A D$ \\
\hline 6. ay & $309,0 \pm 49,3$ & $305,0 \pm 52,8$ & $331,0 \pm 62,1$ & $296,0 \pm 55,2$ & $\mathrm{AD}$ \\
\hline 12. ay & $325,0 \pm 51,2$ & $330,7 \pm 67,1$ & $324,0 \pm 84,7$ & $333,0 \pm 41,9$ & $A D$ \\
\hline \multicolumn{6}{|l|}{ Ferritin $(\mathrm{ng} / \mathrm{mL})$} \\
\hline Doğum & $294,2 \pm 160,7$ & $208,1 \pm 97,9$ & $252,7 \pm 133,0$ & $185,0 \pm 102,0$ & $<0.001^{*}$ \\
\hline \multicolumn{6}{|c|}{ Transferin doygunluğu (\%) } \\
\hline Doğum & $30,4 \pm 20,5$ & $27,0 \pm 19,2$ & $28,4 \pm 17,0$ & $35,8 \pm 18,8$ & $A D$ \\
\hline 3. ay & $12,8 \pm 6,8$ & $12,7 \pm 4,7$ & $15,3 \pm 7,1$ & $15,1 \pm 9,4$ & $A D$ \\
\hline 6. ay & $11,7 \pm 5,7$ & $11,1 \pm 4,6$ & $8,3 \pm 3,8$ & $12,5 \pm 5,9$ & $A D$ \\
\hline 12. ay & $13,3 \pm 9,1$ & $12,6 \pm 7,1$ & $10,1 \pm 7,4$ & $11,6 \pm 4,9$ & $A D$ \\
\hline
\end{tabular}

AD: Anlamlı değil, * Grup 1 ile Grup 4 arasında anlamlı 


\begin{tabular}{|l|c|c|c|c|}
\hline \multicolumn{2}{|c|}{ Tablo 5. Değişik yaş gruplarındaki bebeklerde anemi görülme sıklıkları } \\
\hline \multirow{2}{*}{ Yaş } & $\begin{array}{c}\text { Grup 1 } \\
\text { (\%) }\end{array}$ & $\begin{array}{c}\text { Grup 2 } \\
\text { (\%) }\end{array}$ & $\begin{array}{c}\text { Grup 3 } \\
\text { (\%) }\end{array}$ & $\begin{array}{c}\text { Grup 4 } \\
\text { (\%) }\end{array}$ \\
\hline Doğumda & 10,0 & 7,4 & 15,7 & 6,2 \\
3. ay & 8,0 & 8,3 & 5,3 & 6,7 \\
6. ay & 40,0 & 50,0 & 57,1 & 69,2 \\
12. ay & 25,0 & 12,5 & 22,0 & 22,2 \\
\cline { 2 - 5 } & & & \\
\hline
\end{tabular}

AD : Anlamlı değil

rak anlamlı derecede yüksek bulundu $(p<0,001)$. Uçüncü ay sonunda hızlı kullanım sonucu serum ferritin düzeylerinin yaklaşık dört kat azaldığı ancak gruplar arasında anlamlı fark bulunmadığı gözlendi. Altıncı ayda serum ferritin düzeylerinde azalmanın devam ettiği ve yarı değerlere indiği, Hb değerlerinin ise üçüncü aydaki değerlerin üzerine yükseldiği anlaşıldı. On ikinci aydaki değerlerin de yaklaşık birbirine benzer değerler olduğu gösterildi.

Doğumda yaklaşık \%10 bebekte, üçüncü ayda ise yaklaşık $\% 7$ bebekte anemik değerler görüldü. Altıncı ay sonunda bu oranlar \%50,5 gibi yüksek değerlere ulaştı (Tablo 5). Bu nedenle anemik gebelerden doğan bebeklerin \%91'ine, anemik olmayan gebelerden doğan bebeklerin ise \%61,4'üne altıncı aydan itibaren demir desteği başlanma gerekliliği ortaya çıktı. Demir eksikliği anemisi gelişmesinde gebelerdeki demir depolarının etkisinin az olduğu, süt çocukluğu dönemindeki beslenme ve demir desteği verilmesinin daha anlamlı olduğu düşünüldü.

\section{Tartıșma}

Demir eksikliği gebelerde var olmasına karşın, gebelik sırasında demirin anneden bebeğe geçiş özelliğinden dolayı gebelerde demir eksikliği daha belirgin duruma gelmektedir. Bu gebelerden doğan bebeklerde doğum sonrası ilk üç ayda demir eksikliği gözlenmemektedir. Bu nedenle gebelerde demir desteği yanında, doğan bebeklerine de üçüncü aydan sonra demir desteği verilmesi önemlidir. Yetersiz kalındığı durumlarda hızla demir eksikliği ve demir eksikliği anemisi gelişmektedir $(15,16)$.

Gebelik başlangıcında demir depoları yeterli olsa da gebeliğin son dönemlerinde plazma hacimlerinde artış nedeniyle anemi gelişir. Gebeden bebeğe en yoğun demir geçişi gebeliğin 30. haftası döneminde gerçekleşir. Eğer, gebede demir durumu kötü ise plasental geçişin almaç sayısı arttırılarak bebeğe yeterli demir geçişi sağlanmaya çalışılır $(17,18)$. Killbride ve ark. (6) çalışmalarında gebelik anemisinin süt çocuğunda demir eksikliği gelişiminde önemli etken olduğu, ancak bebeğin demir durumunun kordon kanı değerlerinden bağımsız oluştuğunu öne sürmüşlerdir. Doğumdan sonraki beslenme, sık enfeksiyon geçirilmesi, parazit bulunması, sosyal durumun düşüklüğü, kronik hastalıklar ve demir desteğinin yetersiz yapılması demir eksikliği gelişimini tetiklemektedir. Kısa gebelik süresi ya da intrauterin gelişme geriliği sonrası doğan bebekler yetersiz demir depoları nedeniyle benzer şekilde anemi gelişimine adaydır.

Çalışma grubunda yer alan gebelerde anemisi olmayan ve demir desteği alanlarda $\mathrm{Hb}$, hematokrit ve depo demir değer- leri doğum anında gebeliğin 14. haftasına göre belirgin yüksek bulundu. Buna karşın gebelik süresince demir desteği almayan gebelerde doğumda serum ferritin düzeyleri belirgin azalmıştı. Anemisi olan ve demir desteği alan gebelerden doğan bebeklerde doğumda halen anemik değerlerin varlığı demirin uygun verilmemesi, emilimin bozulmuş olması ya da gebelik öncesi depoların yetersiz olması ile açıklanabilir.

Bebeklerin değerlendirilmesinde, sadece serum ferritin düzeyleri anemisi olmayan ve demir desteği alan gebelerden doğan bebeklerde, doğumda anemik ve demir desteği almayan gebelerden doğan bebeklere göre anlamlı derecede yüksek bulundu. Bhargava ve ark. (19) düzenledikleri çalışmada $\mathrm{Hb}$ düzeyi $6 \mathrm{~g} / \mathrm{dL}$ ve altında belirgin anemik gebelerden doğan bebeklerde $\mathrm{Hb}$ ve serum ferritin düzeylerinin hafif anemik gebelerden doğan bebeklere göre daha yüksek olduğunu göstermişler ve bu değerlerin fetal hipoksi nedeniyle yükseldiğini açıklamışlardır. Buna karşın Ahmad ve ark. (20) çalışmalarında anemik olmayan gebelerden doğan bebeklerin kord kanı $\mathrm{Hb}$ düzeyini, anemik gebelerden doğan bebeklere göre belirgin yüksek olduğunu gözlemlemişlerdir. Benzer çalışmalarda anne ferritin düzeylerinin bebeklerin kord kanı ferritin düzeyleri ile uyumlu olduğu gösterilmiştir $(21,22)$. Ancak, anne yeterli besleniyorsa, gebelik sırasında demir durumunun yetersiz olmasının bebeğe demir geçişinin engellenmesine neden olmadığını gösteren çalışmalar da vardır (23). Çalışmamıza benzer bir diğer çalışmada ise gebelerin yarısında demir eksikliği ve anemisi bulunmasına karşın bebeklerinde doğumda demir düzeyleri açısından anlamlı fark oluşmamıştır (24).

Üçüncü ayda bebeklerde bütün kan değerlerinin belirgin azaldığı görüldü. Doğumdaki değerlere göre en belirgin azalma dört kat olmak üzere serum ferritin düzeylerinde ve iki kat olmak üzere $\mathrm{Hb}$ değerlerinde gerçekleşti. Bu sonuçlara benzer olarak Preziosi ve ark. (25) gebelikte demir desteği alan gebelerden doğan bebeklerde serum ferritin düzeyini daha yüksek bulmuşlardı. Doğum sonrası ilk üç aylık dönemde oksijenlenmenin artması, eritropoietin düzeyinde azalma ve $\mathrm{Hb}$ tipinin $\mathrm{HbF}$ tipinden giderek $\mathrm{HbA}$ tipine doğru değişmesi sonucu $\mathrm{Hb}$ düzeylerinde belirgin azalma gerçekleşmektedir. Buna bağlı olarak değerler yaşamın en düşük değerlerine ulaşmaktadır.

Bu çalışmada, altıncı aya ulaşıldığında demir eksikliği anemisi gelişme oranının \%50’ye yükseldiği görülmektedir. Ayrıca, gebelerde var olan demir durumunun, bebeklerinde altıncı ve on ikinci aylarda gelişen demir durumu ile uyumlu olduğu gözlenmiştir. Morton ve ark. (26) yapmış oldukları çalışmada çalışmamızı destekleyen benzer sonuçlara ulaşmışlardır. Murray ve ark. (27) ise zencilerde yaptıkları çalışmada bebeklerin altıncı 
aydaki demir durumu ile gebelerin demir durumunu uyumlu bulmamışlardır. Üçüncü ayda sadece \%7 olan demir eksikliği anemisi oranının daha sonraki dönemde hızla artması nedeniyle, ülkemizde özellikle Doğu Anadolu Bölgesi'nde üçüncü aydan sonra her bebeğe demir desteği verilmesi düşünülmelidir.

Demir eksikliği belirtilerinin ilk üç ay içerisinde ortaya çıkmadığı, ancak anemik gebelerden doğan bebeklerde on ikinci aya ulaşılmadan belirginleştiği, bu nedenle altıncı ay sonrasında demir desteği gerekliliği değişik çalışmalarda vurgulanmıştır (26,28-30). Tamamlanan bu çalışmada da altıncı aydaki verilerde demir eksikliğinin belirginleştiği gözlendi. Üçüncü aydan sonra tam olarak hangi ayda belirginleştiği, daha sık aralarla kan örneği alınmasının etik olmayacağı düşünüldüğünden, saptanamadı. Bu nedenle üçüncü aydan sonra düzenli destek yapılmasının uygun olduğu düşünüldü. Ayrıca çalışmaya katılan bebeklerin üçte ikisinin ilk altı ay süresince yalnız anne sütü ile beslendiği göz ardı edilmemelidir.

Demir eksikliği anemisi geliştikten sonra yapılan demir tedavisi ile bilişsel bozukluklarda düzelmenin oluştuğu, ancak psikomotor düzelmenin yetersiz kaldığı vurgulanmaktadır (19). $\mathrm{Bu}$ denli önemli sonuçlara yol açabilen toplum sorunu olan demir eksikliği anemisinin önlenmesinde, demir eksikliğinin erken dönemde tanımlanması ve hızlı bir şekilde demir desteğinin gerçekleştirilmesine başlanması gerekmektedir.

Sonuç olarak anemik değerlerin bebeklerin üçüncü aydaki değerlerinde görülmemesi, buna karşın altıncı ayda ise bebeklerin yaklaşık yarısında demir eksikliği anemisinin ortaya çıkması nedeniyle, ülkemiz Doğu Anadolu Bölgesi'nde doğan tüm bebeklere zamanında ve uygun dozda demir desteği verilmesi gereklidir. Gebelik süresince gebelere demir desteği verilmesinin bu durumu önlemede yeterli olmadığı da gösterildiğinden ve süt çocukluğu dönemindeki beslenme daha anlamlı olduğundan bu destek kesinlikle uygulanmalıdır. Son iki yıldır bu konuda birinci basamak sağık kuruluşlarında Sağık Bakanlığı tarafından yapılan uygulama bu çalışma tarafından da desteklenmiştir.

\section{Çıkar çatışması: Bildirilmedi}

\section{Kaynaklar}

1. Allen LH. Anemia and iron defeiciency. Effects on pregnancy outcome. Am J Clin Nutr 2000; 71: 1280-4.

2. Gümrük F, Altay Ç. Demir metabolizması ve demir eksikliği anemisi. Katkı Pediatri Dergisi 1995; 16: 265-85.

3. World Health Organization (WHO) Nutritional anemias report of a. WHO Scientific Group Technical Report Series No: 405, 1968.

4. International Nutritional Anemia Consultative Group (INACG). Measurement of iron status. Washington DC: The Nutrition Services, 1995.

5. World Health Organization. The prevalence of anemia in women: A tabulation of available information. 2nd ed. Geneva: World Health Organization, 1992.

6. Kilbride J, Becker TG, Parapia LA, et al. Anemia during pregnancy as a risk factor for iron deficiency anemia in infancy: a case control study in Jordan. Int J Epidemiol 1999; 28: 461-8.
7. Colomer J, Colomer C, Gutierez D, et al. Anaemia during pregnancy as a risk factor for infant iron deficiency report from Valencia Infant Anaemia Cohort (VIAC) study. Paediatr Perinatol Epidemiol 1990; 4: 196-204.

8. Booth I, Aukett M, Logan S. Iron deficiency anemia in infancy and early childhood. Arch Dis Child 1997; 76. 549-54.

9. Cavla EB, Grazzo V. Prevalence of iron deficiency in children aged 924 months from a large urban area of Argentina. Am J Clin Nutr 1990; 52: $534-40$

10. Lozoff B, Wolf AW, Jimenez E. Iron deficiency anemia and infant development: Effects of extended oral iron therapy. J Pediatr 1996; 129: 382-9.

11. Kalayoğlu Beşışık S. Demir eksikliği anemisi. Türkiye Klinikleri Hematoloji Dergisi 2004; 2: 96-102.

12. Fletcher J, Suter PE. The transport of iron by the human placenta. Clin Sci 1969; 36: 209-29.

13. Bergamaschi G, Bergamaschi P, Carlevati S, et al. Transferin receptor expression in the human placenta. Hematologica 1990; 75: 220-3.

14. Milman N, Ibsen KK, Christensen JM. Serum ferritin and iron status in mothers and newborn infants. Acta Obstet Gynecol Scand 1987; 66: 205-16.

15. Fairweather TSJ. Iron deficiency in infancy; easy to prevent or is it? Eur J Clin Nutr 1992; 46: 9-14.

16. Lönnerdal B, Dewey KG. Epidemiology of iron deficiency in infants and children. Annals Nestle Nutrition Services 1995.

17. Hemminki E, Rimpela U. Iron supplementation, maternal packed cell volume and fetal growth. Arch Dis Child 1991; 94: 277-80.

18. Singla PN, Tyagi M, Kumar A, et al. Fetal growth in maternal anemia. J Trop Pediatr 1997; 43: 89-92.

19. Bhargava M, Kumar R, lyer PU, et al. Effect of maternal anaemia and iron depletion on foetal iron stores, birthweight and gestation. Acta Paediatr Scand 1989; 78: 321-3.

20. Ahmad SH, Matto GM, Amir M, et al. Hematological profile of babies of anemic mothers. Indian Pediatr 1984; 21: 753-61.

21. Kumar A, Rai AK, Basu S, et al. Cord blood and breast milk iron status in maternal anemia. Pediatrics 2008; 121: e673-7.

22. Akhter S, Momen MA, Rahman MM, et al. Effect of maternal anemia in fetal outcome. Myemensingh Med J 2010; 19: 391-8.

23. Ervasti M, Sankilampi U, Heinonen S, et al. Early signs of maternal iron deficiency do not influence the iron status of the newborn, but are associated with higher infant birthweight. Acta Obstet Gynecol Scand 2009; 88: 83-90.

24. Paiva Ade A, Rando PH, Paqliusi RA, et al. Relationship between the iron status of pregnant women and their newborns. Rev Saude Publica 2007; 41: 321-7.

25. Preziosi P, Prual A, Galan P, et al. Effect of iron supplementation on the iron status of pregnant women: Consequences for newborns. Am J Clin Nutr 1997; 66: 1178-250.

26. Morton RE, Nysenbaum A, Price K. Iron status in the first year of life. J Pediatr Gastroenterol Nutr 1988; 7: 707-19.

27. Murray MJ, Murray AB, Murray NJ, et al. The effects of iron status of Nigerian mothers on that of their infants at birth and 6 months, and the concentration of Fe in breats milk. Br J Nutr 1978; 39: 627-57.

28. Yalcin SS, Yurdakok K, Acikgoz D, et al. Short term developmental outcome of iron prophylaxis in infants. Pediatr Int 2000; 42: 625-30.

29. Childs F, Aukett A, Darbyshire P, et al. Dietary education and iron deficiency anemia in the inner city. Arch dis Child 1997; 76: 144-7.

30. Kavukcu S, Taneli NN. Comparison of serum and breast milk ferritin with some hematological parameters in the perinatal period. J Assoc Physicians India 1994; 42: 875-82. 